\title{
Assessment of Left Ventricular Diastolic Function in Children with HIV/AIDS Attending a Tertiary Health Facility in Enugu, Nigeria: A Doppler Echocardiographic Study.
}

ljeoma 0. Arodiwe

Department of Paediatrics, Faculty of medical Sciences, University of Nigeria Nsukka

Christopher B. Eke ( $\nabla$ christopher.eke@unn.edu.ng )

Department of Paediatrics, Faculty of medical Sciences, University of Nigeria Nsukka

\section{Research Article}

Keywords: Diastolic dysfunction, Children, HIV/AIDS, Echocardiography

Posted Date: July 9th, 2021

DOI: https://doi.org/10.21203/rs.3.rs-634621/v1

License: (c) (1) This work is licensed under a Creative Commons Attribution 4.0 International License. Read Full License 


\section{TITLE PAGE}

Assessment of Left Ventricular Diastolic Function in Children with HIV/AIDS Attending a Tertiary Health Facility in Enugu, Nigeria: A Doppler Echocardiographic Study.

IO Arodiwe, ${ }^{1,2} \mathrm{CB} \mathrm{Eke}^{1,2}$

\section{Affiliations:}

${ }^{1}$ Department of Paediatrics, College of Medicine, University of Nigeria Enugu Campus, Nigeria

${ }^{2}$ Department of Paediatrics, University of Nigeria Teaching Hospital, Ituku- Ozalla, Enugu, Nigeria

\section{Correspondence:}

Prof CB Eke

Department of Paediatrics, College of Medicine, University of Nigeria Enugu Campus. Enugu, Nigeria.

Tel: $+234-8030504785$

E- mail: christopher.eke@unn.edu.ng 


\section{ABSTRACT}

Objective: To determine the prevalence and factors associated with left ventricular diastolic dysfunction (LVDD) in children aged between 18 months and 14 years with HIV/AIDS.

Method: echocardiography was performed on 90 children with HIV/AIDS and their age and gender matched healthy controls.

Results: Forty three (47.8\%) of the HIV/AIDS patients had LVDD. This was more pronounced in the AIDS group with all $(100 \%)$ affected, compared to $\mathrm{HIV}^{+}$carriers $(36.5 \%)$ and controls $(2.2 \%), \mathrm{p}=0.03$. The E/A ratio increased from $1.90 \pm 0.56 \mathrm{~m} / \mathrm{s}$ in the carrier group to $2.09 \pm 0.46 \mathrm{~m} / \mathrm{s}$ in AIDS group, $\mathrm{p}=0.01$. Left ventricular isovolumic relaxation time increased from $79.40 \pm 20.12 \mathrm{~m} / \mathrm{s}$ (HIV carrier group) to $110.40 \pm 10.12 \mathrm{~m} / \mathrm{s}$ (AIDS group), $\mathrm{p}=0.04$, and deceleration time (DT) increased from $184.66 \pm 76.27 \mathrm{~m} / \mathrm{s}$ (HIV carrier group) to 230.66 \pm 36.27 (AIDS group), $p=0.02$. A restrictive filling pattern was the most described in both groups. Positive correlation was found between body surface area and LVDD. Stepwise linear regression analysis showed this to be the predictor of LVDD. In the HIV group, total white cell count correlated negatively with LVDD, while in the AIDS group, age correlated positively with $\operatorname{LVDD}(\mathrm{r}=-0.459, \mathrm{p}=0.024$ and $\mathrm{r}=0.874, \mathrm{p}=0.023$ respectively).

Conclusion: There is a high prevalence of LVDD in children with HIV and AIDS. Need exists to integrate routine cardiovascular assessment using echocardiography, particularly in those with AIDS as part of their standard case management for early identification and appropriate interventions to save lives.

Key words: Diastolic dysfunction, Children, HIV/AIDS, Echocardiography. 


\section{INTRODUCTION}

HIV/AIDS is one of the leading health problems globally, especially in sub-Saharan Africa, where the most profound impact is evident, accounting for ninety-five percent of HIV related infections and deaths [1]. This disease is characterized by a deficient cell-mediated immunity resulting in profound immunosuppression with clinical manifestations including multiple opportunistic infections, malignancies and progressive dysfunction of multiple organ systems $[2,3]$.

One of the organs affected is the heart. Evidence of cardiac involvement in HIV/AIDS may be clinically quiescent initially $[4,5]$. Although the endocardium, myocardium, pericardium and vasculature may be affected, the myocardium remains the most vulnerable and this may present as myocarditis, dilated cardiomyopathy or isolated left or right ventricular dysfunction $[4,5]$. The first report of cardiac involvement was by Austran, Gorin and Leibowitch in Haiti in 1983 [6].Recent studies have reported that HIV may exhibit a cardiac tropism and that cardiac complications contribute significantly to morbidity and mortality in HIV infected children $[4,5]$. As a result of availability of anti-retroviral (ARV) drugs and treatment of opportunistic infections, HIV infection has emerged to become a chronic disease. There are still very few HIV infected children accessing ARV therapy especially in developing countries because of financial constraints. ARV drugs do not eliminate the disease from the body; their use may simply postpone the development of heart disease. Some of the drugs like Zidovudine are cardiotoxic and have been linked with heart disease [5].

Although the endocardium, myocardium, pericardium and vasculature may be affected, the myocardium remains the most vulnerable.The reported prevalence of left ventricular diastolic dysfunction in HIV infection from several studies in Europe and America varies from $2 \%$ to over 40\%, [6-10] with symptomatic heart failure developing in $6 \%$ of these patients [7,11], most of who have end-stage disease, AIDS [5,8,11]. 
In sub-Saharan Africa where the burden of the disease is very high, involvement of the heart by HIV has become a clinical problem over the last decade, but there are a few published controlled studies on it $[1,5,12]$. There was no documentation of diastolic dysfunction in some of these studies due to unavailability of Doppler echocardiography.

The aim of our study was to evaluate left ventricular diastolic function (LVDF) and factors affecting it in children with HIV/AIDS in a Nigerian Urban city compared with age and gender matched unaffected controls, using two dimensional Doppler echocardiography. 


\section{SUBJECTS AND METHODS}

This was a cross sectional descriptive study carried out over a period of eleven months from August 2016 to May, 2017 at the paediatric outpatient clinic of the University of Nigeria Teaching Hospital (UNTH), Ituku/Ozalla, Enugu.

Subjects were ninety paediatric HIV and AIDS children and adolescents aged 18months -14years. Also, 90 (100.\%) HIV seronegative age and sex matched children attending the paediatric outpatients clinics for minor ailments including malaria and upper respiratory tract infections who were consecutively recruited served as controls. The patients had positive HIV serology and a clinical diagnosis of HIV infection according to CDC criteria and they were classified into 2 groups: HIV-infected group with 74 (\%) patients and AIDS group with 16 (\%) patients. Patients who are on medications with known cardiovascular effects, children with pre - existing cardiac diseases, chronic diseases associated with demonstrable wasting or oedema were excluded.

All the study participants were black children with at least one parent or guardian who gave an informed consent. Ethical clearance was also obtained from UNTH ethics committee.

Clinical assessment using a questionnaire was obtained. Blood was drawn for heamoglobin $(\mathrm{Hb})$ measurement and erythrocyte sedimentation rate (ESR), $\mathrm{CD}^{+}$cell count (performed by a slide technique with APAAP mouse monoclonal antibody [Dako, glostrup, Denmark]) and HIV serology. Antibody level against HIV were measured by an enzyme linked immunosorbent assay and confirmed by western blotting.

\section{Echocardiographic technique and measurements[14]}

M mode, cross - sectional, and Doppler echocardiographic examinations were performed with Hewlett-Packard SONO 2000 machine with a 5.5-12MHz multi transducer, wide phased array transducer. The operators were blind to the HIV and clinical status of the study groups. 
The younger subject who was not cooperative in the presence of their caregiver or parents was pacified with toys or sedated with a mild short acting sedative, chloral hydrate as appropriate. This was given half an hour before the procedure and aqua sonic gel used to ensure effective contact of the transducer with the chest wall. Older children were placed in a left lateral position and examined in the standard subcostal, apical, parasternal long and short axis and suprasternal views. Using the cross sectional images as a guide, the M- mode tracing of the left ventricle was obtained to calculate measurements according to the recommendations of the American Society of Echocardiography [15].

The following variables were measured: left ventricular end diastolic and end systolic dimensions, interventricular septal and left ventricular posterior wall thickness in diastole for calculating left ventricular mass (Devereux's formula), left ventricular fractional shortening (FS\%), early peak (VE) and late peak (VA) velocity (VE/VA) ratio, isovolumic relaxation time (IVRT), and deceleration half time of the early filling period (DHT). Three cycles were analyzed and average values were calculated. The IVRT is the interval from the closure of the aortic valve until mitral valve opening. It was measured by continuous wave imaging from the apical window, displaying aortic and mitral flow together.

\section{Defining normality}

The normal mean (sd) IVRT value is $71(14) \mathrm{ms}$. The mitral deceleration time (DT) is the time period from the peak of the VE wave until the end of early diastolic filling, normal mean(sd) value is 199 (32) ms. Normal values for other variables are as follows: VE, $0.86(0.16) \mathrm{ms}$; VA, $0.56(0.13) \mathrm{ms}$; VE/VA ratio, $1.6(0.4)$; left ventricular mass index, $110-134 \mathrm{~g} / \mathrm{m}^{2}$; left ventricular end diastolic dimension (LVEDD), $<5.5 \mathrm{~cm}$; and FS\% $>28 \%$. The normal reference values used for the analysis of diastolic function in this work were obtained from available literature and are appropriate for the studied population [16-18]. 
Standardized criteria for defining abnormalities:

LV diastolic dysfunction was adjudged present in the presence of any of the following criteria:E/A ratio $<1$, IVRT $>100 \mathrm{~m} / \mathrm{s}$ and DT> $220 \mathrm{~m} / \mathrm{s}$ (impaired relaxation pattern); pseudonormalization resembling the normal configuration with respect to the mitral inflow but with low DT;E/A ratio $>2$, IVRT $<70 \mathrm{~m} / \mathrm{s}$ and DT $<150 \mathrm{~m} / \mathrm{s}$ (Restrictive pattern).

\section{Statistical analysis:}

Statistical Package for Social Sciences (SPSS) version 20.0 was used to enter and analyze the data. Descriptive statistics for continuous variables were expressed as mean (SD). Qualitative variables were presented as percentage or frequencies and compared between the HIV - infected, AIDS and controls groups. Test of association between the groups were determined using one way ANOVA or chi-square test as appropriate. A pvalue $<0.05$ was considered statistically significant. Pearson's and Spearman Rho correlation were used to assess the relations between LV diastolic dysfunction as dependent variable and independent variables affecting it. Significant variables were further analyzed using the stepwise linear regression analysis. 


\section{RESULTS}

\section{Study characteristics}

Ninety patients were recruited consecutively for the study. Out of this, $74(82.2 \%)$ were HIV infected and 16 $(17.8 \%)$ had AIDS. Ninety age and sex matched controls were also recruited for the study. The characteristics of the study participants are shown in Table 1 . The mean weight, height and BMI for age were significantly higher in the controls than the HIV and AIDS group, F 21.3, p <0.001; F 6.28, p = 0.002; $\chi^{2} 337.81(2-4 \mathrm{yrs}), 240.08$ (59yrs) and 94.11(10-14yrs), $\mathrm{p}<0.001$ respectively. The mean respiratory rate, heart rate, diastolic blood pressure and erythrocyte sedimentation rate were significantly higher in the AIDS group. Similarly, the mean systolic blood pressure, haemoglobin level, white blood cell count and CD4+ cell count were significantly lower in the AIDS group than others, F 5.14, p 0.007; F 127.93, p < 0.001; F 23.02, p < 0.001; and F 8.93, p < 0.001respectively. The AIDS group also had a significantly higher number of persons with severely depressed CD4+ cell count and lower number of those with total CD4+ cells higher or equal to 1500 cells $/ \mathrm{mm}^{3}$ although the later did not reach statistical significance, $\chi^{2} 5.6, p=0.01 ; \chi^{2} 4.54, p=0.05$, Table 1 .

\section{Prevalence of LVDD and echocardiographic findings in the study population}

Table 2 showed the echocardiographic findings in the study participants. LVDD was present in 43 of the 90 children with HIV and AIDS. This gave an overall prevalence of 47.8\%. However, prevalence of LVDD was significantly higher in AIDS group with all of them, 16 (100.0\%) being affected, when compared with twentyseven out of $74(36.5 \%)$ of patients with HIV - infection and only $2.2 \%$ in controls $\left(\chi^{2} 1.23, p=0.03\right)$. The mean left ventricular mass index was significantly higher in the HIV and AIDS group compared to the controls, F 9.47, $\mathrm{p}<0.001$. The mean E/A ratio, IVRT, DT, LVEDd, and LVESd were significantly higher in the AIDS group compared to the others, F 2.03, $\mathrm{p}=0.01 ; \mathrm{F} 2.11, \mathrm{p}=0.04 ; \mathrm{F} 0.37, \mathrm{p}=0.02 ; \mathrm{F} 0.70, \mathrm{p}=0.02 ;$ and $\mathrm{F} 3.30, \mathrm{p}=0.01$; respectively, Table 2. A restrictive filling pattern was the most described in both groups, Figures 1and 2. 
Factors associated with LVDD

Among the HIV group, body surface area (BSA) correlated positively with LVDD, $r=0.425, p=0.038$; while total WBC count correlated negatively, $\mathrm{r}=-0.459, \mathrm{p}=0.024$. In the AIDS group, age of the patients and their BSA correlated positively, $r=0.874, p=0.023$ and $r=0.824, p=0.042$ respectively, Table 3 . Stepwise logistic regression analysis showed BSA as the only predictor of LVDD in both HIV and AIDS group, Table 4. 


\section{DISCUSSION}

Our study demonstrated that HIV/AIDS infection is associated with both increased LV mass index and diastolic dysfunction. Diastolic dysfunction was found in $43(47.8 \%)$ of these children (HIV/AIDS combined) and in $100 \%$ of those with AIDS. Uwanuruochi [19] in Enugu in an adult population reported a prevalence of diastolic dysfunction of $29 \%$ in HIV/AIDS patients, while Ige et al [20] in Jos reported 30.7\%. Lipshultz, et al [21]in Boston reported 39\%. These observed differences in prevalence rate might be due to differences in study design and bias in patient selection in terms of matching for age and sex.Again there may be some racial or genetic predisposition to the prevalence [20,22].Of the diastolic indices the most common significant variation was an increased atrial contribution to ventricular filling in the HIV- infected and AIDS group. This has also been reported by various workers $[20,23]$.However decreased myocardial compliance was more frequent in the left ventricle and abnormal relaxation was noted in the right. The reversal of filling pattern is likely to be due to left ventricular hypertrophy which is known to lead to incoordination and impaired relaxation,especially as the HIVinfected subjects in present study had significantly elevated left ventricular mass index [20].Arodiwe et al [24] in a previous study in Enugu had reported left ventricular systolic dysfunction in $27.0 \%$ of our patients. This was also seen in some published reports which showed that $10-40 \%$ of HIV infected patients had left ventricular systolic dysfunction $[25,26]$. Left ventricular wall thickness and mass index tended to be increased in the HIV and AIDS population in comparison with normal subjects, and this was significant as wall thickening and fibre elongation contribute to the pattern of concentric hypertrophy [24-26].

Some authors noted that left ventricular diastolic impairment is an important pathophysiologic mechanism reflecting the symptoms of congestive heart failure [20, 23, 25]. However, our study did not document congestive heart failure in these patients. It may be due to heart failure often being a late manifestation of diastolic dysfunction $[20,23]$.The significance of a high prevalence of diastolic dysfunction relates to its association with morbidity and mortality (27). HIV-infected children are predisposed to diastolic dysfunction as an independent 
predictor of all-cause mortality, and the exact pathogenesis of cardiac events remains uncertain, but it is most likely multifactorial $[28,29]$. In adults, an independent association between diastolic dysfunction and HIV infection was reported in a series of studies, even among asymptomatic HIV-infected patients in the early stages of the disease [30-32]. To prevent complications, the assessment of subclinical cardiac abnormalities was suggested.

The mean weight in the AIDS group was significantly lower than the controls. This is expected as the loss of lean body mass especially muscle protein has been well documentedin HIV-infection [33, 34].In the absence of HIV infection, weight loss has been known to be associated with decrease in left ventricular mass, left ventricular volume and ventricular function $[33,34]$.However the presence of increased left ventricular mass index indicating LVH in our patients with HIV infection may be an indication that some other factors, such as proto-oncogene activation can modulate the hypertrophic response [35].This may have counteracted the usual effects of malnutrition on cardiac muscles. It remains possible that inadequate nutrition may have contributed to the subnormal hypertrophic responses relative to left ventricular dimension observed in patients with HIV - infection [35].

One of the objectives of this study was to determine risk factors for diastolic dysfunction. The variables investigated for their potential association with diastolic dysfunction included age, pulse rate, blood pressure, Body Surface Area (BSA), CD4+ cell count, stage of disease (CD4+ classification), total white blood cell count, haemoglobin level among others, BSA and total WBC only correlated significantly with LVDD in the HIV group, the former positively and the later negatively. In the AIDS group, age and BSA correlated with LVDD positively. These findings are difficult to explain. Positive correlation of BSA with diastolic dysfunction suggests that the higher the body surface area, the higher the prevalence of diastolic dysfunction. Body surface area was also the only predictor of LV diastolic dysfunction in our study. This finding is at variance with Lipshultz et al [21] and Lobato, et al [36], who noted the presence of HIV encephalopathy as a predictor of LV dysfunction in HIV/AIDS 
infection. This difference may be due to their study population ( perinatally acquired HIV infected children). The timing of the study may have also influenced the finding, as this was when prevention of mother to child transmission of HIV programme was not a global priority [37].

In the HIV group, the lower the total white blood cell count, the more likely diastolic dysfunction was present. This agrees with the report of Herskowitz et al [38], although in adults, who found a median CD4+ cell count of $30 / \mu 1$ compared to a median count of $187 / \mu \mathrm{l}$ in those without ventricular dysfunction. Lower CD4+ cell count is a marker of terminal disease associated with HIV cardiomyopathy and a rapid course of disease progression with end organ affectation [39].

Age of the patients correlated positively with LVDD in the AIDS group. This suggests that the older the patient, the higher the prevalence of diastolic dysfunction. This could be explained by the fact that the virus and its effects on the heart muscle and other effects have had more time to occur. Ige et al [20], in a similar study in middle belt region of Nigeria noted that their subjects with LVDD were older than those without though this did not reach statistical significance. Increased left ventricular mass is often found to underlie diastolic dysfunction [23, 39]. This may be related to an increase in sympathetic tone, a manifestation of autonomic dysfunction. This in turn raises the concentration of catecholamines eventually leading to myocardial hypertrophy. Higher left ventricular mass which predisposes to LVDD has been shown to be more common in older HIV-infected children [23, 39]. Other risk factors predisposing to diastolic dysfunction like tachycardia, blood pressure, haemoglobin level, and stage of infection appear not to correlate with LVDD in this study. This was also the observation of Ige et al [20]. The cross sectional nature of our study could account for this. A longitudinal study may help to fully determine the relationship of these variables and LVDD in children with HIV/AIDS.

In conclusion, the present study showed that LVDD is prevalent in children with HIV/AIDS who are asymptomatic of heart failure. The echocardiographic indices of LV diastolic function and the prevalence of LVDD were significantly higher in the HIV/AIDS group compared to controls. Body surface area was the only 
predictor of LVDD. Total WBC correlated with LVDD in the HIV group while age of patients correlated with LVDD in those with AIDS.

This underscores the need for integrating routine baseline and periodic cardiovascular assessment using echocardiography, particularly in those with AIDS as part of their standard case management in order to determine those with LVDD and appropriate interventions applied to save lives.

\section{Limitations}

Our work is not without limitations especially those related to the design, since a non-probabilistic, convenience sample was used, limiting the external validity of these results. The selection bias, inherent to investigations in referral centers, was considered in the sample composition, when the authors planned to study all potentially eligible children. The presence or absence of a pre-existing cardiac abnormality prior to enrolment into the study was based on medical records of the patients. This however, may not completely exclude an underlying cardiac abnormality, as clinical evaluation only is inadequate, as shown in the HIV-negative controls that had cardiac abnormalities. The methods used in this study to assess LVDD are limited by the confounding effects of physiologic variables including LV relaxation, compliance and filling pressure. Alterations in these variables will cause abnormal Doppler indices and as such make it difficult to exactly determine the true meaning of a given finding when examining Doppler filling patterns observed. Unfortunately we do not have access to newer technologies of LV diastolic function assessment in our center and in most centers in sub-Saharan Africa. 


\section{$\underline{\text { Declarations: }}$}

\section{Abbreviations:}

AIDS: Acquired Immune deficiency syndrome

BSA: Body surface area

DHT: Deceleration Half Time

FS: fractional shortening

HIV: Human immune deficiency syndrome

IVRT: Isovolumic relaxation time

LVEDD: Left ventricular end diastolic dimension

UNTH: University of Nigeria Teaching Hospital

\section{Ethics approval and consent to participate:}

Ethical approval was obtained from the Health Research Ethics Committee of the University of Nigeria Teaching Hospital, Ituku- Ozalla, Enugu.Informed written consents were obtained from parents /guardians of the children while assent was obtained from children 7years and older respectively.

Consent for publication: Not applicable

Conflicts of interest: None declared

Availability of data and materials: The datasets used/or analysed during this study are available from the corresponding author on reasonable request.

Competing interests: The authors declare that they have no competing interests.

Funding/Financial support: The study was solely funded by the researchers. This research received no specific grant from any funding agency, commercial or not-for-profit sectors. 


\section{Authors' contributions:}

IO Arodiwe: Conceived the paper, oversaw data collection, conducted data analysis, initial manuscript draft and critical editing of manuscript for important intellectual content.

CB Eke: Critical editing of manuscript for important intellectual content.

\section{All authors approved the final draft.}

Acknowledgements: The authors acknowledge the support of colleagues from the Paediatric cardiology unit of the University of Nigeria Teaching Hospital, Enugu for their moral support. 


\section{REFERENCES}

1. Lubega S, Zirembusi GW, Lwabi P: Heart Disease among Children with HIV/AIDS attending the paediatric infectious disease clinic at Mulago Hospital. Afr Health Sci. 2005; 5: 219-226.

2. Grant A D, De Cock K M. HIV infection and AIDS in the developing world. BMJ 2001; 322: 1475-1478.

3. Austran B, Gorin I, Leibowitch M. AIDS in a Haitian woman with cardiac Kaposi's sarcoma and Whipple disease. Lancet 1983; 1: 767-768.

4. Longo-Mbenza B, Tonduangu K, Kintonki VE. The effect of HIV infection on high incidence of heart disease in kinshasa (Zaire). Echocardiographic study. Ann Cardio Angeiol (Paris). 1997; 46: 81-87.

5. Longo-Mbenza B, Segher KV, Phuati M. Heart involvement and HIV infection in African Patients: determinants of survival. Int J Cardiol 1998;13; 64: 63-73.

6. Shah 1, Prabhu SS, Shashikiran HS. Cardiac dysfunction in HIV infected children: a pilot study. Indian Paedtr. 2005; 42: 46-49.

7. Tovo PA, Demartino M, Gabiano C, Cappelo N, D’Elia R, Loy A. Prognostic factors and survival in children with perinatal HIV-1 infection. Lancet 1992; 339: 1249-1253.

8. National Guideline for Paediatric HIV and AIDS Treatment and care October 2010

9. Herskowitz A, Wu TC, Willoughby SB. Myocarditis and cardiotropic viral infection associated with severe left ventricular dysfunction in late-stage infection with human immunodeficiency virus. J Am Coll Cardiol 1994; 24: 1025-1032.

10. Heymsfield SB, Head CA, McManus CB III. Respiratory, cardiovascular, and metabolic effects of enteral hyperalimentation: Influence of formula dose and composition. Am J ClinNutr 1994; 40: 116-130

11. Cardoso J S, Miranda A M, Moura B, Gomes M H, Oliveira P. Cardiac morbidity in the HIV infection. Rev Port Cardiol 1994; 13: 901-911

12. Okoroma CAN, Ojo OO, Ogunkule OO. Cardiovascular dysfunction in HIV-infected children in a Sub- 
Saharan African Country: Comparative Cross-sectional Observational Study. Journal of Trop Paediatr. 2012;58:3-11. Doi: 10.1093/tropej/fmr009.

13. Schiller NB, Shah PM, Craford M, DeMaria A, Devereux R, Feigenbaum H et al. Recommendations for quantification of left ventricle by two dimensional echocardiography. America Society of Echocardiography committee on standards, sub-committee on quantitation of two -dimensional echocardiograms. J Am SocEchocardiogr 1989; 2: 358-376.

14. ACC/ AHA/ASE 2003 guidelines update for the clinical application of echocardiography: A report of the American College of Cardiology/ American Heart Association Taskforce on Practice guidelines. Circulation 2003; 108-1146.

15. Lai WW, Geva T, Shirali GS, Frommelt PC, Humes RA, Brook MM et al. Guidelines and standards for performance of a pediatric echocardiogram: A report from the Task Force of the Pediatric Council of the American Society of Echocardiography. J Am SocEchocardiogr 2006; 19:1413-30.

16. Kaddoura S. Doppler- velocities and pressures. In: Kaddoura S, Editor. Echo Made Easy. $2^{\text {nd }}$ ed. ChurchHill Livingstone Elsevier 2009:12-13.

17. Adewole AA, Okechukwu SO, Akeyemi AA, Dike BO, Olulola OO, Ayodele OF. Echocardiogrphic reference values in healthy Nigerians. NJC. 2006; 3: 30-36.

18. Uwanuruochi K. Evaluation of left ventricular function of HIV-infected adults seen at UNTH Enugu. FMCP Part II Dissertation, National Postgraduate Medical College of Nigeria 2008.

19. Ige OO, Oguche S, Yilgwan CS, Bode-Thomas F. Left ventricular mass and diastolic dysfunction in children infected with the human immunodeficiency virus. Nig J Cardiol 2014;11:8-12

20. Lipshultz SE, Fisher SD, Miller TL, Sharma TS, Milton AN. The cardiovascular manifestations of HIV infection. Dialog Cardiovasc Med 2007;12:5-23.

21. Ugochukwu EF. Clinical spectrum of paediatric HIV in Nnewi, Nigeria. West Afr J Med. 2006; 25: 10-14. 
22. Hsue PY, Hunt PW, Ho JE, Farah HH, Schnell A, Hoh R et al. Impact of HIV infection on diastolic function and left ventricular mass. Circ Heart Fail 2010; 3:132-9.

23. Arodiwe IO, Obidike EO, Ikefuna AN,Anisuba SN,Arodiwe EB,Ibeziako SNet al. Left Ventricular Systolic function in Nigerian Children infected with HIV/AIDS: a cross-sectional study. Cardiovasc J Afr 2016; 27:00-00. DOI:5830/CVJA-2015-066

24. Mondy KE, Gottdiener J, Overton ET, Henry K, Bush T, Conley L et al. High prevalence of echocardiographic abnormalities among HIV-infected persons in the era of highly active antiretroviral therapy. Clin Infect Dis 2011; 52: 378-86.

25. Kardys I, Deckers JW, Stricker BH, Vletter WB, Hofman A, Witteman JC. Echocardiographic parameters and all-cause mortality: The Rotterdam study. Int J Cardiol 2009; 133:198-204.

26. Fisher SD, Easley KA, Orav EJ, Colan SD, Kaplan S, Starc TJ et al. Mild dilated cardiomyopathy and increased left ventricular mass predict mortality: The prospective P2C2 HIV Multicenter Study. Am Heart J 2005; 150:439-47.

27. Kumar P, Hemal A, Pensi T, Kumar D, Nath R, Khurana R. Cardiovascular manifestation of HIV infected children: A cross-sectional study. (Poster Presentation at the $49^{\text {th }}$ National Conference of Indian Academy of Pediatrics, January 18-22, 2012).

28. Wislowska M, Jaszczyk B, Kochmañski M, Sypua S, Sztechman M. Diastolic heart function in RA patients. Rheumatolint 2008; 28:513-9.

29. Lebech A, Gerstoft J, Hasse B, Peterson C L, Kjaer A. Right and left ventricular cardiac function in a developed world population with HIV studied with radionuclide ventriculography. Am Heart J 2004; 147: $482-488$.

30. Nayak G, Ferguson M, Tribble DR, Porter CK, Rapena R, Marchicelli M et al. Cardiac diastolic dysfunction is prevalent in HIV-infected patients. AIDS Patient Care STDS, 2009. 231-238 
31. Schuster I, Thöni GJ, Edérhy S, Walther G, Nottin S, Vinet A et al.Subclinical cardiac abnormalities in human immunodeficiency virus-infected men receiving antiretroviral therapy. Am J Cardiol, 2008: 12131217

32. Brown SC, C.J. Schoeman CJ, Bester CJ. Cardiac findings in children admitted to a hospital general ward in South Africa: a comparison of HIV-infected and uninfected children Cardiovasc J S Afr, 2005: 206210

33. Miller TL, Orav EJ, Colan SD, Lipshultz SE, Nutritional Status and cardiac mass and function in children infected with the human Immunodeficiency virus. Am J ClinNutr 1997; 66: 660-664.

34. Longo - Mbenza B, Seghers KV, Vita EK. Assessment of ventricular diastolic function in AIDS patients from Congo: a Doppler Echocardiographic study. Heart 1998; 8: 184 - 189.

35. Lobato MN, Caldwell B, Ng P, Oxtoby MJ. Encephalopathy in children with perinatally acquired human immunodeficiency virus infection. J Paediat. 1995; 126: 710-715.

36. UNIADS. Joint United Nations Programme on HIV/AIDS. Report on the global HIV/AIDS epidemic. June 2008.

37. Herskowitz A, Willoughby SB, Baughman KL, Schulman SP, Bartlett JD. Cardiomyopathy Associated with Antiretroviral Therapy in Patients with HIV Infection: A Report of Six Cases. Ann Intern Med 1992; 116: $311-313$.

38. Ram Y, Ellen GC. Acquired Immunodeficiency Syndrome (Human Immunodeficiency Virus). In: Behrman RE, Kliegman RM, Jenson HB, Editors; Nelson text book of pediatrics, $17^{\text {th }}$ ed. Philadelphia: Saunders, 2004:1109-1120.

39. Ganan A, Devereux RB, Roman MJ, de Simone G, Pickering TG, Saba PS et al. Patterns of left ventricular hypertrophy and geometric remodeling in essential hypertension. J Am Coll Cardiol 1992; $1550-8$. 
Table 1. Characteristics of the study participants.

\begin{tabular}{|c|c|c|c|c|c|}
\hline Characteristics & $\begin{array}{l}\text { HIV infection } \\
\mathrm{N}=74\end{array}$ & $\begin{array}{l}\text { AIDS } \\
\mathrm{n}=16\end{array}$ & $\begin{array}{l}\text { controls } \\
n=90\end{array}$ & $\mathrm{~F} / \chi^{2}$ & - value \\
\hline Mean age (years) & $8.15 \pm 3.08$ & $7.9 \pm 2.07$ & $8.3 \pm 3.04$ & 0.14 & 0.87 \\
\hline \multicolumn{6}{|l|}{ Gender } \\
\hline Male & 38 & 9 & 49 & & \\
\hline Female & 36 & 7 & 41 & 0.654 & 0.06 \\
\hline Mean weight (kg) & $14.43 \pm 9.67$ & $10.22 \pm 6.07$ & $22.4 \pm 9.42$ & $21.30<0$ & 0.001 \\
\hline Mean height $(\mathrm{cm})$ & $108.1 \pm 20.9$ & $95.7 \pm 15.3$ & $114.7 \pm 21.8$ & 6.28 & 0.002 \\
\hline \multicolumn{6}{|l|}{ Mean BMI for age } \\
\hline $2-4$ years & $18.3 \pm 2$ & $16.4 \pm 2$ & $22 \pm 3.1$ & & \\
\hline$(\mathrm{m} / \mathrm{f})$ & $18.8 \pm 1$ & $16 \pm 2$ & $22.5 \pm 2.1$ & 337.81 & $<0.001$ \\
\hline $5-9$ years & $16.7 \pm 1$ & $15.8 \pm 1.2$ & $23.2 \pm 2.9$ & & \\
\hline$(\mathrm{m} / \mathrm{f})$ & $16.3 \pm 1.2$ & $15.5 \pm 1.5$ & $23.5 \pm 2.4$ & 240.08 & $<0.001$ \\
\hline $10-14$ years & $17.5 \pm 0.8$ & $16.3 \pm 2$ & $21.5 \pm 2$ & & \\
\hline$(\mathrm{m} / \mathrm{f})$ & $17.1 \pm 0.9$ & $16.3 \pm 0.5$ & $20.4 \pm 3$ & 94.11 & $<0.001$ \\
\hline Mean RR/min & $29 \pm 5$ & $32 \pm 6$ & $26 \pm 5$ & 13.12 & $<0.001$ \\
\hline Mean HR/min & $103 \pm 18$ & $120 \pm 20$ & $92 \pm 13$ & 25.05 & $<0.001$ \\
\hline Mean SBP (mmHg) & $89 \pm 8$ & $81 \pm 12$ & $85 \pm 12$ & 5.14 & $<0.007$ \\
\hline Mean DBP (mmHg) & $52 \pm 8$ & $60 \pm 7$ & $54 \pm 7$ & 7.76 & 0.001 \\
\hline Mean HB (g/dl) & $9.8 \pm 1.1$ & $8.6 \pm 0.7$ & $11.6 \pm 0.7$ & 127.93 & $<0.001$ \\
\hline Mean WBC (cells/ $\mu 1)$ & $6813 \pm 2056.3$ & $4059 \pm 1838.2$ & $5059 \pm 1838.2$ & 23.02 & $2<0.001$ \\
\hline Mean ESR (mm/1 $\left.{ }^{\mathrm{st}} \mathrm{hr}\right)$ & $31 \pm 10.6$ & $67 \pm 12.4$ & $6.3 \pm 2.4$ & 486.40 & $<0.001$ \\
\hline
\end{tabular}




\begin{tabular}{ccllll}
\hline Mean CD4+ $\left(\right.$ cells $\left./ \mathrm{mm}^{3}\right)$ & $1486.6 \pm 158.6$ & $504.6 \pm 300.3$ & $1786.6 \pm 1582.6$ & 8.93 & $<0.001$ \\
CD4+ (cells $\left./ \mathrm{mm}^{3}\right)$ & & & & & \\
$\leq 1499, \mathrm{n}(\%)$ & $6(8.1)$ & $15(93)$ & $30(3.3)$ & 5.6 & 0.01 \\
$\geq 1500, \mathrm{n}(\%)$ & $68(92)$ & $1.1(6.9)$ & $87(96)$ & 4.54 & 0.05 \\
\hline
\end{tabular}

Key: BMI - Body mass index, $\mathrm{m}$ - male, $\mathrm{f}$ - female, RR - Respiratory rate, HR - Heart rate, SBP - Systolic blood pressure, DBP - Diastolic blood pressure, HB - Haemoglobin, WBC - White blood cell count, ESR - Erythrocyte sedimentation rate. 
Table 2: Echocardiographic characteristics of the study participants.

\begin{tabular}{lcllll}
\hline Characteristics & HIV infection & AIDS & Control & F/ & $\mathrm{p}$ \\
& $\mathrm{N}=74$ & $\mathrm{n}=16$ & $\mathrm{n}=90$ & $\chi^{2}$ & \\
\hline Prevalence of LVDD. N $(\%)$ & $27(36.5)$ & $16(100)$ & $2(2.2)$ & 1.23 & 0.03 \\
Mean LVMI $\left(\mathrm{g} / \mathrm{m}^{2}\right)$ & $90.4 \pm 25.3$ & $89.4 \pm 25.1$ & $74.5 \pm 23.2$ & 9.47 & $<0.001$ \\
Mean E/A ratio & $1.9 \pm 0.56$ & $2.09 \pm 0.46$ & $1.20 \pm 0.39$ & 2.03 & 0.01 \\
Mean IVRT(m/s) & $79.4 \pm 20.12$ & $110.4 \pm 10.12$ & $89.22 \pm 25.76$ & 2.11 & 0.04 \\
Mean DT(m/s) & $184.66 \pm 76.27$ & $230.66 \pm 56.27$ & $174.10 \pm 38.24$ & 0.37 & 0.02 \\
Mean LVDd(mm) & $5.96 \pm 0.6$ & $6.75 \pm 0.6$ & $3.75 \pm 0.72$ & 0.70 & 0.02 \\
Mean LVESd(mm) & $2.65 \pm 0.18$ & $3.75 \pm 0.36$ & $2.69 \pm 0.18$ & 3.30 & 0.01
\end{tabular}

Key: LVMI - Left Ventricular Mass Index, E/A ratio - Early/Atrial mitral inflow velocities, IVRT - Isovolumic Relaxation Time, DT - Deceleration time, LVEDd - Left Ventricular End Diastolic dimension, LVESd - Left Ventricular End Systolic dimension, LVDD Left Ventricular Dystolic Dysfunction. 
Table 3. Correlation of independent variables with diastolic function in HIV/AIDS patients.

\begin{tabular}{lcccc}
\hline Parameters & \multicolumn{2}{c}{ HIV infection } & \multicolumn{2}{c}{ AIDS } \\
& $\mathrm{r}$ & $\mathrm{p}$ & $\mathrm{r}$ & $\mathrm{p}$ \\
& & & & \\
\hline Age & 0.320 & 0.127 & 0.874 & 0.023 \\
BMI & 0.104 & 0.628 & -0.199 & 0.706 \\
Pulse rate & -0.301 & 0.152 & -0.254 & 0.627 \\
BSA & 0.425 & 0.038 & 0.827 & 0.042 \\
SBP & -0.183 & 0.392 & 0.000 & 1.000 \\
DBP & -0.150 & 0.485 & -0.684 & 0.134 \\
LVMI & -0.013 & 0.951 & 0.003 & 0.951 \\
HB & -0.193 & 0.365 & -0.682 & 0.135 \\
WBC-T & -0.459 & 0.024 & -0.169 & 0.749 \\
ESR & 0.033 & 0.878 & 0.422 & 0.404 \\
CD4 cell count & -0.392 & 0.058 & -0.266 & 0.610
\end{tabular}

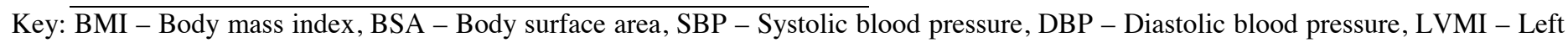
ventricular mass index, HB - Haemoglobin, WBC - White blood cell count, ESR - Erythrocyte sedimentation rate. 
Table 4: Stepwise logistic regression of factors that correlate with $\mathrm{LV}$ diastolic dysfunction in the HIV/AIDS patients ${ }^{\mathrm{a}}$

\begin{tabular}{|c|c|c|c|c|c|c|}
\hline \multirow[t]{2}{*}{ Model } & \multicolumn{2}{|c|}{$\begin{array}{l}\text { Unstandardized } \\
\text { coefficient }\end{array}$} & \multicolumn{2}{|c|}{$\begin{array}{l}\text { Standardized } \\
\text { coefficient }\end{array}$} & \multirow[b]{2}{*}{$\mathrm{p}$} & \multirow[b]{2}{*}{$95 \%$ confidence interval } \\
\hline & $\mathrm{B}$ & $\mathrm{SE}$ & Beta & $\mathrm{t}$ & & \\
\hline Constant & 0.061 & 0.332 & & 0.183 & 0.856 & $-0.620-0.741$ \\
\hline BSA & 1.367 & 0.348 & 0.596 & 3.923 & 0.001 & $0.653-2.081$ \\
\hline
\end{tabular}

a. Dependent variable: LV diastolic dysfunction 


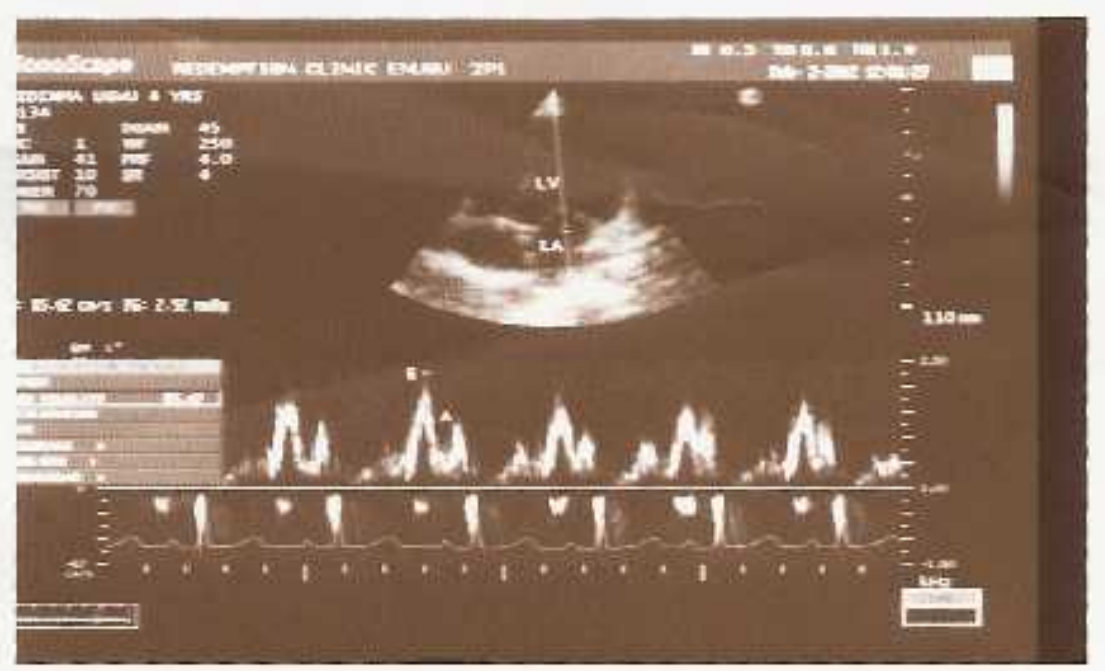

Figure 1: Pulsed wave Doppler showing restrictive pattern of the mitral inflow velocities E and A in HIV patients

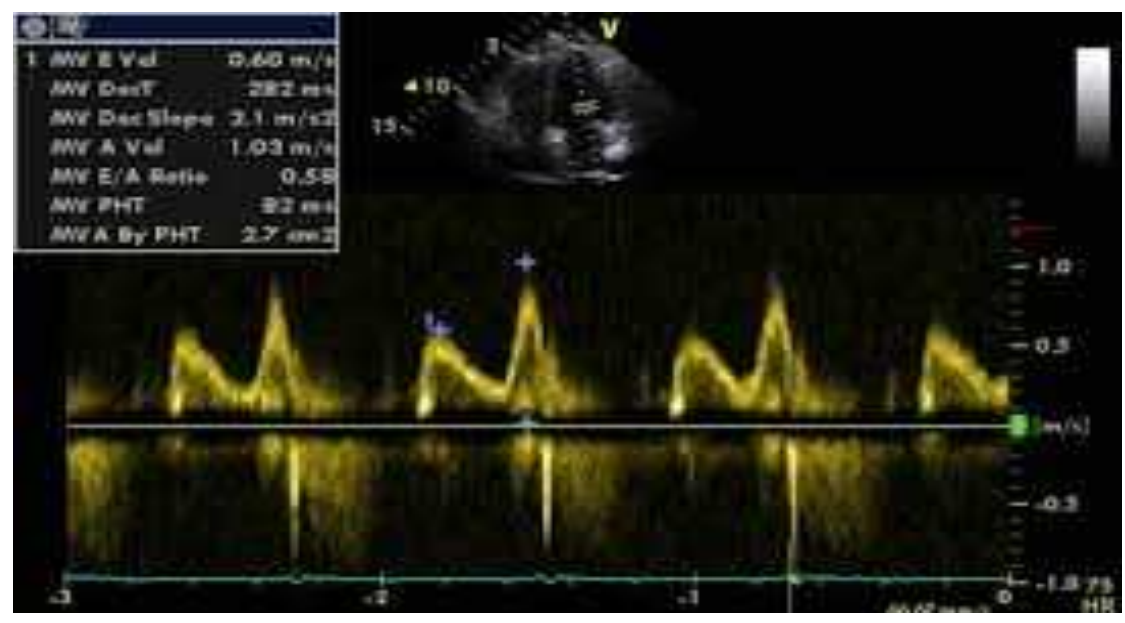

Figure 2: Pulsed wave Doppler showing restrictive pattern of the mitral inflow velocities E and A in AIDS patients 